\title{
TOURISM MANAGEMENT: A PANACEA FOR SUSTAINABILITY OF HOSPITALITY INDUSTRY
}

\author{
Morgan Obong MORGAN* \\ University of Calabar, Department of Business Management, Nigeria, e-mail: m_morgan24@yahoo \\ Emmanuel Ekpenyong OKON \\ University of Calabar, Department of Business Management, Nigeria, e-mail: emmany2k9@yahoo.com \\ Winifred Harry EMU \\ University of Calabar, Department of Educational Management, Nigeria, e-mail: okonwinfred@ yahoo.com \\ Osho-Itsueli E. OLUBOMI \\ College of Education, Department of Economics, Nigeria, e-mail: bomioshoitsueli@gmail.com \\ Hope Ukam EDODI \\ University of Calabar, Department of Business Management, Nigeria, e-mail: hopeedodi@gmail.com
}

\begin{abstract}
Citation: Morgan, M.O., Okon, E.E., Emu, W.H., Olubomi, O.I.E., \& Edodi, H.U. (2021). TOURISM MANAGEMENT: A PANACEA FOR SUSTAINABILITY OF HOSPITALITY INDUSTRY. GeoJournal of Tourism and Geosites, 37(3), 783-791. https://doi.org/10.30892/gtg.37307-709
\end{abstract}

\begin{abstract}
The aim of the study is to examine the effect of tourism management as a panacea for sustainability of hospitality industry in Nigeria. The study applied a quantitative method involving a survey design. A questionnaire measurement instrument was constructed and deployed on a sample of 455 respondents in the hotels, packs, tourism destinations and attraction sites included in the study. Exploratory Factor Analysis (EFA) was used to validate the constructs in the measurement instrument. Structural Equation Model (SEM) was used to estimate structural relationship between tourism management dimensions and sustainability of hospitality industry. The analysis was aided by AMOS software version 23 . The results showed that destinations management, management of attraction sites, management of tourist transportation system, management of tourism intermediaries and management of security system has significant positive effect on the sustainability of hospitality industry. Therefore, the study concluded that effective tourism management and adoption of workable strategies is vital for the development and growth of the tourism sector and significant towards enhancing the tourism ecosystem and sustainability of hospitality industry.
\end{abstract}

Key words: tourism management, sustainability, hospitality industry, destinations, attraction sites.

$* * * * * *$

\section{INTRODUCTION}

In an era of global pandemic which affected virtually all sectors of the economy of nations, particularly developing countries, Nigeria inclusive; effective tourism management is significant for the recovery and sustainability of hospitality industry, economic growth and employment generation. While corona virus pandemic affected all industries, its influence on the hospitality industry is evidence due in part to travel restrictions, lockdowns imposed by state and federal agencies and significant postponement of events as well as social distancing restrictions, leading to cancelation of holidays and business trips which cause a steep decline in hospitality firms revenue and as well impeded the hospitality industry in Nigeria, requiring effective tourism management to salvage the menace. Tourism management is the planning, coordination, controlling, and organising several activities in destinations, attraction sites, transportation systems, provisions of hotel accommodations, tours, intermediaries and effective management of security network of the state/region to ensure the safety and security of tourist and others visitors, hotels assets, destinations, the host community and the environment as well as to ensure the sustainability of hospitality industry (Ekundayo et al., 2018). In recent time, tourism management have become one of the cardinal themes of research due to its significance to the sustainability of hospitality industry and communities. The sustainability of hospitality industry has continued to receive global attention by researchers due to its significance in employment generation and economic growth of nations, particularly developing countries. The sustainability of hospitality industry is the capacity of firms in the industry to maintain and operate at a particular rate or level over a long period of time while remaining profitable and sustainable (Todorut and Cîrnu, 2012).

However, poor destination management, lack of infrastructure, transportation system and poor security network has impeded on the growth of tourist destinations and attractions sites in developing countries like Nigeria. A tourist destination is a location which has the required services, infrastructure, security, transportation system, accommodation and other facilities necessary to attract and meet tourist desires and enhance their stay in the destination (Soteriades, 2012). Destination management encompasses the planning, organising and coordination of activities such as attractions, amenities,

\footnotetext{
* Corresponding author
} 
marketing, tours, accommodations and events that enhances tourist and visitor's experience (Timareva et al., 2015). Also poor management and development of attraction sites affect the growth of tourist destination as well as the sustainability of hospitality industry. Attraction sites are major component of tourism destination which are located within the destinations. They are key product of the tourism destination including tourism activities, entertainment, services/leisure, natural/cultural value, local scenery, built beauty, amusement, events and heritage (Barišiü and Mariü, 2012).

Importantly, lack of effective management of transportation systems and good road network to and around tourism destinations affects the sustainability of hospitality industry. Efficient transportation systems and good road network in and around the destination and attraction sites as well as hotels enhances tour of the destinations and attraction sites by tourist and enhances tourist holidaying in the destination which impacts on the profitability and sustainability of the hospitality industry. Further, despite the significance contribution of tourism intermediaries on the sustainability of hospitality firms, tourism intermediaries have continued to face challenges due to poor management of intermediaries activities including tour agents, travel operators, wholesalers, retailers and distributors which impeded on the performance of destinations as well as the hospitality industry (Isidoro and Pilar, 2020). Similarly, the poor management of security networks in tourism destinations, attractions sites, transportation systems and intermediaries activities as well as in tourism location, state or region have continued to impede on the performance of destinations, attraction sites, parks and hotels which affect the overall sustainability of the hospitality industry particularly in developing countries. Effective security system is important for the smooth operation of the hospitality industry and ecotourism activities. Improving security network in a state or region as well as in and around tourism destinations enhances tourist tour, comfort, confidence, loyalty and repeated patronage. Also, effective security management ensures the protection of destinations, attraction sites and hotels asset which enhances the sustainability of the hospitality industry. Despite the significance of destinations management, management of attraction sites, tourist transportation system, tourism intermediaries and security systems in enhancing the sustainability of the hospitality industry, greater attention has not been given to tourism management issues with dire consequences on the sustainability of hospitality industry (Malheiro et al., 2020; Gaetano et al., 2021). Hence, the motivation to examine the five factors/dimensions of tourism management such as destinations management, management of attraction sites, tourist transportation system, tourism intermediaries and security systems on the sustainability of hospitality industry. However, although the concept of tourism management and sustainability has gain prominence as a field of study in management in recent time, little attention has been given by researchers on the influence of tourism management as a catalyst to the sustainability of hospitality industry that deserves a systematic examination. Therefore, this paper aims to bridge this gap by investigating tourism management as a panacea for sustainability of hospitality industry.

\section{LITERATURE REVIEW}

Tourism management is significant and plays a vital role in enhancing the sustainability of hospitality industry. It encompasses several activities including planning and organising tours of destinations and attraction sites, travelling arrangement, provision of transportation and accommodation facilities, management of intermediaries and security network in tourism destinations to improve sustainability of the hospitality industry (Brebbia and Pineda, 2012). Effective tourism management is important and offers significant impact on the growth and sustainability of hospitality industry. As indicated by Todorut and Cîrnu (2012), tourism is the management of commercial organisation and operation of holidays and visits by tourist and other guest to attraction sites, destinations, hotels, packs and other places of interest. Effective tourism management is significant for the sustainability of hospitality firms and plays a key role in job creation and economic growth. It is important for state agencies and other tourism regulators to ensure effective tourism management and development of tourism destination and attraction sites in order to improve the potentials and sustainability of hospitality industry. This is necessary because the activities of tourism regulators has significant influence on the performance of hospitality firms (VillanuevaÁlvaro et al., 2017). Effective management of destinations, attractions sites, transportation systems as well as tourism intermediaries and security network is important in the tourism development and sustainability of hospitality industry. Proper tourism management enhances tourist holidaying and guest stay in a destination and leads to improved patronage and repeat visits to the destination and other attraction sites. Study by Barišiü and Mariü (2012) indicated that effective tourism management relates with performance of hospitality industry and enhances tourism growth and development.

\section{Destinations management}

In recent time, destination management have continued to dominate the discussion in the tourism management literature due to its significance to the sustainability of the hospitality industry and the development of the tourism sector, particularly in developing nations. Destination management encompasses the planning, organising and coordination of activities such as attractions, amenities, marketing, tours, accommodations and events targeted at enhancing tourist and visitors experience in the destination (Foris et al., 2020). It involves the development of policies, strategies and programmes that will create awareness on the unique story and attractiveness of the tourist destinations in order to attract tourist and visitors to the destination, and as well enhancing the revenue of the destination and the sustainability of the hospitality industry. A tourism destination is a geographical region or place with attractions and facilities that can enhance tourist experience as well as generate significant revenue from tourism. Effective destination management is germane to the success of tourism sector and the sustainability of hospitality industry (Goffi et al., 2019).

Iwara et al. (2017) indicated that effective destination management improved the provision of modern facilities, accommodations, amenities, security and continuous improvement of services offered in the destination, thereby providing memorable tourist and visitors experience as well as increasing tourist/visitors influx in the destinations which results in 
increased revenue generation for the sustainability of the hospitality industry. Paresashvili and Maisuradze (2016) emphasized that ensuring the availability of required technology and internet facilities in the destination enhances tourist experience and enables tourist and visitors to have information/data on the quality of services, amenities and attractions as well as images of the destination which could motivate tourist to visit the destination. Also, such facilities will enable tourist write reviews about their experiences in the destination which could create awareness on the destination; as such reviews maybe shared in different social media platforms. Effective destination management enhances the development of the destinations, tourism supply, facilities/infrastructure, improved services and attract repeat visit by tourist and visitors to the destinations (Zemla, 2016; Chia et al., 2021). Study by Timareva et al. (2015) indicated that destination management enhances tourism development and impacts on the performance of hospitality firm.

\section{Management of attractions sites}

Attraction sites are important aspect of a destination which enhances tourist and visitors experience. Adequate management of attractions sites contributes to the development of tourism sector in a nation as well as the sustainability of the hospitality industry (Setokoe, 2021). Attraction sites are areas, region or places which have unique features such as exhibited cultural and natural value, historical importance, built beauty, heritage, events or natural environment and other facilities that are of interest and enhance visitors and tourist experience (Leask, 2016). Adequate management of attraction sites enhances the development of destinations as well as the tourism sector and lead to improved revenue generation and sustainability of hospitality firms. Mazilu (2010) indicated that effective management of attractions sites increases the potentials of a destination and enhances tourist and customers' patronage, since well-managed and developed attraction sites grab tourist attention and entice them for a visit, thereby increasing the influx of tourist and visitors in a destination. Proper management of the attraction sites encompasses the planning, coordination and development of facilities/infrastructures in the attraction sites to improve visitors experience as well as developing strategies that could ensure the continuous maintenance of equipment, facilities and improve services in the attraction sites. Barišiü and Mariü (2012) indicated that adequate management of parks and other attraction sites impacts significantly on the development and growth of tourism in a nation. Similarly, study by Richards (2002) revealed that attractions sites relate significantly with the performance of the tourism industry.

\section{Management of tourist transportation systems}

Transportation systems are an integral aspect of tourism development and play a vital role in enhancing the viability of destinations and attraction sites. Adequate management of tourist transportation systems enhances accessibility to destination and attraction sites as well as tour experience for both tourist and visitors. Management of transportation system is the planning and coordination of transportation activities and networks including road, sea, rail and air transport to tourist destinations and attraction sites as well as within and outside the location to improve accessibility to the destinations and enhance visitors and tourist comfort (Eden, 2005). Improved management of transportation system increases transportation options for recreational travel to destinations and attraction sites as well as reducing traffic in destinations and attractions sites (Lomhmann and Duval, 2011). However, effective transportation systems are important to tourism development and critical in moving tourist and visitors from one destination to another. Accessibility to tourism destination through modern and improved transportation increases the viability of destinations and attraction sites and leads to increased revenue generation for the sustainability of hospitality industry (Palhares, 2003). Vengesayi et al. (2009) good road network within and outside the tourist destination enhances tour experience within and outside the destinations and attraction sites. It is important to plan strategically for tourist transportation because of its impact on tourist experience and revenue generation capacity of the destination. Alasgarova (2017) indicated that adequate tourist transportation systems impact significantly on the growth of destination and attraction sites as well as the performance of hospitality firms.

\section{Management of tourism intermediaries}

Tourism intermediaries plays important role on the growth of tourism industry and in enhancing tourist experience in the destination. Effective management and regulation of tourism intermediaries contributes to the growth of destinations and the tourism sector as well as the sustainability of the hospitality industry. Management of tourism intermediaries involves the planning, coordination and regulations of activities of intermediaries including distribution and travel agents, tour operators, wholesalers, and online travel agencies to ensure efficient services of intermediaries in order to improve the performance of destinations and tourist experience (Paresashvili and Maisuradze, 2016). Mazilu (2010) indicated that effective management of tourism intermediaries enhances performance of destinations and hospitality industry.

Effective management and regulation of the activities of tourism intermediaries enhances the supply of essential goods and services to the tourism destination which increases the efficiency and service delivery of a destination (Kanellou, 2005). Also, the services of tourism intermediaries such as tour agents, wholesalers, and online travel agencies contribute significantly to tourist and visitors experience. Management of tourism intermediaries is vital since their services involve informing potential tourist and marketing tourism products which could encourage tourist visit to the destination as well as increase the revenue of the destination and performance of the hospitality industry (Foris et al., 2020). Richards (2002) indicated that effective management of tourism intermediaries and attractions impact on the performance of destination and the hospitality industry.

\section{Management of security system}

Security is important for the success of the tourism industry and plays a vital role in protecting tourism infrastructure. Management of security system increases the safety and security of tourist and visitors to a destination. Improved security 
system increases the confidence of tourist and visitors in a destination and encourages repeat visit by tourist. Management of security system involves the planning, organising and coordinating security in tourism destination in order to ensure the protection of tourism infrastructure, facilities, assets, tourist and visitors to tourism destinations (Adora, 2010). Without effective security, tourist cannot successfully explore or visit attraction sites in a destination in order to experience the destinations. The perception of security and safety of a destination by tourist and visitors' influences tourist intention to visit a destination as well as encouraging repeat visit to destinations. It is important to pay particular attention to security management in tourism destinations and attraction sites and develop strategies that will improve the safety and security of tourist and tourism infrastructure in a destination (Vengesayi et al., 2009). Tourism security should be consistent and remain on a high level to ensure the safety of tourist and tourism asset. Effective security management ensures access control that only enables authorized persons, tourist and visitors into the destinations and attraction sites in order to maintain security of the destination for improved tourist comfort. Also, adequate security management ensures proper monitoring and surveillance of tourism destination and prevents unauthorized persons from gaining access to the destination (Hamarneh and Jerabek, 2018). Brondoni (2016) indicated that effective security management increases the security and safety of destination and impact significantly on the performance of hospitality industry.

\section{Sustainability of hospitality industry}

Sustainability of hospitality industry plays important role in economic growth and development, employment generation and contributes significantly to a nations GDP as well as economic recovery, particularly in the post Covid-19 era. Sustainability of the hospitality industry is the ability of hospitality firms in the industry to operate in an economically, socially and environmentally acceptable way while preserving the natural, beauty built facilities/infrastructures, heritage and cultural attractions that motivate tourist to visit the destination as well as efficient utilization of resources in a creative and innovative way in order to operate sustainably over a long period (Brebbia and Pineda, 2012; Setokoe, 2021). Adequate tourism management is significant to the sustainability of hospitality industry and enhances tourist experience in the destination which encourages repeat visit as well as patronage.

Villanueva-Álvaro et al. (2017) indicated that effective tourism management is vital towards enhancing the sustainability of the hospitality industry. Also, proper destinations management is significant towards enhancing tourist/visitors experience, attract repeat visit and increase the revenue generation potential of the destination as well as sustainability of the hospitality industry (Brebbia and Pineda, 2012). Iwara et al. (2017) highlighted that regulators and state tourism management agencies should focus attention on the management and development of tourism attraction sites because of its potentials towards enhancing the sustainability and growth of the hospitality industry. Furthermore, adequate management of tourist transportations systems as well as tourism intermediaries could improve tourist experience, visitors' patronage and sustainability of the hospitality industry. Again, effective management of security system could ensure the safety and security of tourist, visitors and tourism infrastructure/facilities as well as enhancing the sustainability of the hospitality industry (Adora, 2010). Therefore, it becomes important to ensure effective tourism management due to its impact on the sustainability of the hospitality industry and the nation economy in general.

\section{Theoretical background}

The theoretical foundation that motivated the selection of the five factors/dimensions of tourism management (destinations management, management of attraction sites, management of tourist transportation systems and management of security system) utilize in the study was based on the dynamic game theory model for tourism supply chains (Keskin and Ucal, 2021). The theory emphasize the important of utilizing the component of tourism supply such as destination, intermediaries, attractions, transportation and activities to enhance effective tourism management (Keskin and Ucal, 2021). However, Sanhakot (2021) asserted that effective management of security system play a vital role in enhancing tourism management as well as tourism development in a nation, particularly developing countries where issues of security is a constant concern. According to World Tourism Organisation (2021), tourism is sustainable when it fully utilise the tourism supply component in tourism management, thereby enhancing the sustainability of the hospitality industry. Unhasuta et al. (2020) stress the importance of utilizing tourism supply components such as destination, intermediaries, attractions, transportation and activities in tourism management to enhance the eco-tourism sustainability as well as the hospitality industry. Similarly, Tolulope et al. (2021) indicated that proper management of tourism supply is significance to tourism sustainability as well as the hospitality industry. Therefore, it becomes pertinent to examine the five dimensions/factor of tourism supply in enhancing effective tourism management such as (destinations management, management of attraction sites, management of tourist transportation systems and management of security system) on the sustainability of hospitality firms due to their influence on tourism sustainability and the hospitality industry.

\section{The study aim}

The aim of the study is to investigate the effect of tourism management as a panacea for the sustainability of hospitality industry in Nigeria: Specifically, the study examines the effect of:

1. Destinations management on the sustainability of hospitality industry;

2. Management of attraction sites on the sustainability of hospitality industry;

3. Management of tourist transportation systems on the sustainability of hospitality industry;

4. Management of tourism intermediaries on the sustainability of hospitality industry and

5. Management of security system on the sustainability of hospitality industry. 


\section{Hypotheses development}

Based on the literature review, this study proposed the following hypotheses:

$\mathrm{H}_{1}$ : Destinations management has a significant effect on the sustainability of hospitality industry.

$\mathrm{H}_{2}$ : Management of attraction sites has a significant effect on the sustainability of hospitality industry.

$\mathrm{H}_{3}$ : Management of tourist transportation systems has a significant effect on the sustainability of hospitality industry.

$\mathrm{H}_{4}$ : Management of tourism intermediaries has a significant effect on the sustainability of hospitality industry.

$\mathrm{H}_{5}$ : Management of security system has a significant effect on the sustainability of hospitality industry.

\section{MATERIALS AND METHODS}

The study applied a quantitative method involving a survey design to analyse the effect of tourism management as a panacea for the sustainability of hospitality industry in Nigeria. The population of the study was the entire 455 employees from 12 hotels, 3 packs and 10 tourism destinations and attraction sites in Cross River State, Nigeria. The sampling technique adopted for the study was the census method. Since the study adopted the census method, the criteria was to select all the 8 four star and 4 five star hotels, totalling 12 hotels, the entire 3 existing pack and the all the 10 functional tourist destinations currently in operation in the study area. The rationale for this sampling method/criteria for selection was to enable all the 455 employee from the 12 hotels, 3 packs and 10 tourism destinations and attraction sites in the study area full and equal participation in the study since the population of the hotels, packs and destination/attraction sites was manageable and controllable. Based on the survey method employed for the research, questionnaire instrument was developed on the variables of the research and conveniently distributed to the sampled 455 employees in the study area.

The questionnaire instrument was developed to cover the variables of the study; tourism management measured by (destinations management, management of attraction sites, management of tourist transportation systems, management of tourism intermediaries and management of security system) and sustainability of hospitality. The first version of the questionnaire measurement instrument comprised 36 items measuring the six variables: Destinations Management (DM), Management of Attraction Sites (MAS), Management of Tourist Transportation Systems (MTTS), Management of Tourism Intermediaries (MTI), Management of Security System (MSS) and Sustainability of Hospitality Industry (SHI) utilized in the study. In conducting the Confirmatory Factor Analysis (CFA) to test if the measures of the variables are consistent with the aim of the study and to validate the measurement instrument, the Composite Reliability (CR), Standardized Factor Loadings (SFL), Average Variance Extracted (AVE) and Cronbach's alpha coefficients with values of .70 or higher were utilized (Hair et al., 2010). After executing the CFA analysis, ten items were deleted, two each from MTTS, MTI, MSS and MAS variables and one each from DM and SHI variables respectively due to low factor loadings. The remaining 26 items were retained and used in the study. The test of the study hypotheses was performed using SEM analysis to estimate the structural relationship between tourism management (destinations management, management of attraction sites, management of tourist transportation systems, management of tourism intermediaries and management of security system) on Sustainability of Hospitality Industry.

\section{RESULTS}

Table 1 presents the summary results of the means, standard deviations (SD), and correlation matrix of the study variables. As indicated in Table 1, the means were well above 2.5 and standard deviation were all below one in (DM, MAS, MTTS, MTI, MSS and SHI) respectively indicating a good response and clustered around the mean. Also, Table 1 indicated a satisfactory and acceptable discriminant validity of the variables since the square root of AVE between any two variables was higher than the variance share between the variables and other constructs as well as their corresponding intercorrelations (Fornell and Larcker, 1981).

Table 1. Summary results of mean, standard deviation and correlation matrix

\begin{tabular}{|l|c|c|c|c|c|c|c|c|}
\hline \multicolumn{1}{|c|}{ VARIABLES } & Mean & SD & $\mathbf{1}$ & $\mathbf{2}$ & $\mathbf{3}$ & $\mathbf{4}$ & $\mathbf{5}$ & $\mathbf{6}$ \\
\hline Destinations Management (DM) & 4.561 & 0.552 & $\mathbf{0 . 8 1 5}$ & & & & & \\
\hline Management of Attraction Sites (MAS) & 4.463 & 0.636 & 0.401 & $\mathbf{0 . 7 3 7}$ & & & & \\
\hline Management of Tourist Transportation System (MTTS) & 4.211 & 0.473 & 0.376 & 0.352 & $\mathbf{0 . 7 8 7}$ & & & \\
\hline Management of Tourism Intermediaries (MTI) & 4.431 & 0.512 & 0.401 & 0.411 & 0.431 & $\mathbf{0 . 7 7 6}$ & & \\
\hline Management of Security System (MSS) & 4.363 & 0.456 & 0.382 & 0.331 & 0.328 & 0.291 & $\mathbf{0 . 8 6 1}$ & \\
\hline Sustainability of Hospitality Industry (SHI) & 4.018 & 0.367 & 0.360 & 0.357 & 0.287 & 0.397 & 0.316 & $\mathbf{0 . 8 5 2}$ \\
\hline
\end{tabular}

Table 2 presents the results of the CFA analysis. The variables evaluated in the analysis were tourism management (destinations management, management of attraction sites, management of tourist transportation systems, management of tourism intermediaries, and management of security system) and sustainability of hospitality industry. In conducting the CFA analysis, SFL higher than (>.70), AVE (>.50), CR (>.50) and Cronbach Alpha of .70 or higher was used to evaluate the measurement instrument (Hair et al., 2010; Kline, 2015). Furthermore, the results of the CFA in Table 2 showed SFL for the variables in the study, DM variable had SFL range of (0.718-0.880), MAS (0.788-0.854), MTTS (0.817-0.873), MTI (0.801-0.855), MSS (0.731-0871) and SHI (0.799-0.889) respectively. Similarly, the model showed CR range of (0.821-0.889), AVE (0.687-0.792) and Cronbach Alpha range of (0.779-0.887) in MAS, MTTS, MTI, MSS and SHI respectively which was satisfactory and acceptable (Hair et al., 2010; Kline, 2015).

Also, the goodness of fit indices of the measurement model was examine using RMSEA (<0.08), CMIN/DF (<3), CFI (>0.9) and GFI (>0.9) (Hair et al., 2010; Kline, 2015). The results in Table 2 showed (RMSEA 0.058; CMIN/DF 2.824; 
CFI 0.946 and GFI 0.911) for the study variables (DM, MAS, MTTS, MTI, MSS and SHI) respectively, which indicated the goodness of fit of the model and was satisfactory and acceptable. In assessing the results of the collinearity statistic, Tolerance value (>0.2) and Variance Inflation Factors (VIF <5.0) was used (Hair et al., 2010). The result in Table 2 showed that the obtained tolerance values range from (.426-.472) and VIF (1.321-1.624), which was satisfactory and acceptable.

Table 2. Summary of CFA results for the measurement instrument

\begin{tabular}{|c|c|c|c|c|c|c|c|}
\hline \multirow{2}{*}{ Variables } & \multirow{2}{*}{\begin{tabular}{|l|} 
Items \\
Codes \\
\end{tabular}} & \multirow{2}{*}{ SFL } & \multirow{2}{*}{ AVE } & \multirow{2}{*}{ CR } & \multirow{2}{*}{$\begin{array}{c}\text { Cronbach } \\
\text { Alpha }\end{array}$} & \multicolumn{2}{|c|}{ Collinearity Statistics } \\
\hline & & & & & & Tolerance & VIF \\
\hline \multirow{5}{*}{$\begin{array}{l}\text { Destinations } \\
\text { Management } \\
\text { (DM) }\end{array}$} & DM1 & 0.880 & & & & & \\
\hline & DM2 & \begin{tabular}{|l|l|}
0.831 \\
\end{tabular} & & & & & \\
\hline & DM3 & 0.718 & 0.792 & 0.881 & 0.887 & .426 & 1.533 \\
\hline & DM4 & 0.852 & & & & & \\
\hline & DM5 & 0.844 & & & & & \\
\hline \multirow{4}{*}{$\begin{array}{l}\text { Management of } \\
\text { Attraction Sites } \\
\text { (MAS) }\end{array}$} & MAS1 & 0.842 & & & & & \\
\hline & MAS2 & 0.809 & & & & & \\
\hline & MAS3 & \begin{tabular}{|l|l|}
0.788 \\
\end{tabular} & 0.756 & 0.821 & 0.799 & .472 & 1.577 \\
\hline & MAS4 & 0.854 & & & & & \\
\hline \multirow{4}{*}{$\begin{array}{c}\text { Management of } \\
\text { Tourist } \\
\text { Transportation } \\
\text { System (MTTS) }\end{array}$} & MTTS1 & 0.873 & & & & & \\
\hline & MTTS2 & 0.817 & & & & & \\
\hline & MTTS3 & \begin{tabular}{|l|l|}
0.837 \\
\end{tabular} & 0.697 & 0.854 & 0.874 & .431 & 1.478 \\
\hline & MTTS4 & 0.823 & & & & & \\
\hline \multirow{4}{*}{$\begin{array}{c}\text { Management of } \\
\text { Tourism } \\
\text { Intermediaries } \\
\text { (MTI) }\end{array}$} & MTI1 & 0.842 & & & & & \\
\hline & MTI2 & 0.855 & & & & & \\
\hline & MTI3 & 0.801 & 0.687 & 0.859 & 0.861 & .429 & 1.321 \\
\hline & MTI4 & \begin{tabular}{|l|l|}
0.811 \\
\end{tabular} & & & & & \\
\hline \multirow{4}{*}{$\begin{array}{c}\text { Management of } \\
\text { Security System } \\
\text { (MSS) }\end{array}$} & MSS1 & 0.867 & & & & & \\
\hline & MSS2 & 0.731 & 0.736 & 0.851 & 0.882 & .457 & 1.465 \\
\hline & MSS3 & 0.864 & & & & & \\
\hline & MSS4 & 0.871 & & & & & \\
\hline \multirow{8}{*}{$\begin{array}{c}\text { Sustainability of } \\
\text { Hospitality } \\
\text { Industry (SHI) }\end{array}$} & SHI1 & 0.889 & & & & & \\
\hline & SHI2 & 0.822 & & & & & \\
\hline & SHI3 & 0.806 & 0.691 & 0.889 & 0.876 & .445 & 1.624 \\
\hline & SHI4 & 0.799 & & & & & \\
\hline & SHI5 & 0.777 & & & & & \\
\hline & \multicolumn{7}{|c|}{ mary of model fit indexes } \\
\hline & CMIN & $\mathrm{J} / \mathrm{DF}$ & $\mathrm{RM}$ & SEA & CFI & GFI & \\
\hline & 2.82 & & 0.0 & 58 & 0.946 & 0.911 & \\
\hline
\end{tabular}

Note: RMSEA=Mean Square Error of Approximation; CMIN/DF=Chi-Square/ degree of freedom=CFI; Comparative Fit Index; GFI=Goodness of Fit Index
Figure 1 showed the result of path analysis for the questionnaire measurement instrument. Five variables of tourism management (destinations management, management of attraction sites, management of tourist transportation systems, management of tourism intermediaries, and management of security system) and sustainability of hospitality industry were analysed and supported. Also, Figure 2 showed the structural path analysis results which revealed that five hypotheses were examined; including tourism management (destinations management, management of attraction sites, management of tourist transportation systems, management of tourism intermediaries and management of security system), on the sustainability of hospitality industry. Figure 2 showed a standardized beta weights of $0.58,0.56,0.48$, 0.55 , and 0.51 for the study variables. The results indicated that destination management has a $58 \%$ impact on the sustainability of hospitality industry. Also, management of attraction sites has a $56 \%$ influence on sustainability of hospitality industry. Again, management of tourist transportation systems has a $48 \%$ impact on sustainability of hospitality industry. Similarly, management of tourism intermediaries has a $55 \%$ effect on the sustainability of hospitality industry. Lastly, management of security system has a $51 \%$ influence on the sustainability of hospitality industry. These results imply that adequate tourism management influence the sustainability of hospitality industry.

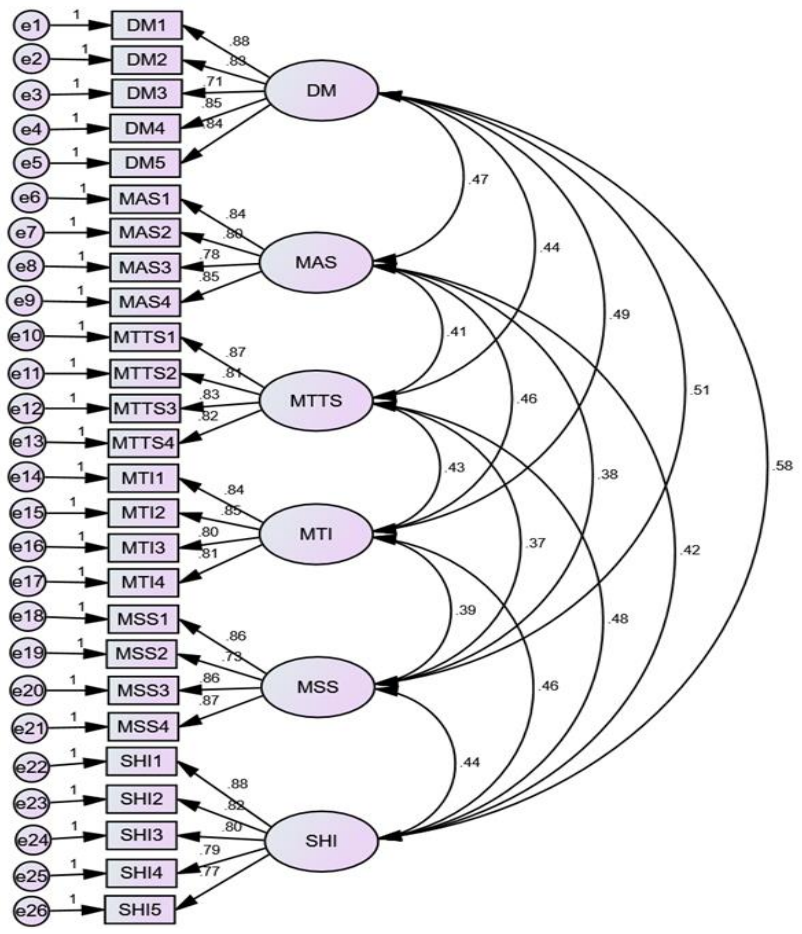

Figure 1. Path analysis results for the questionnaire measurement instrument

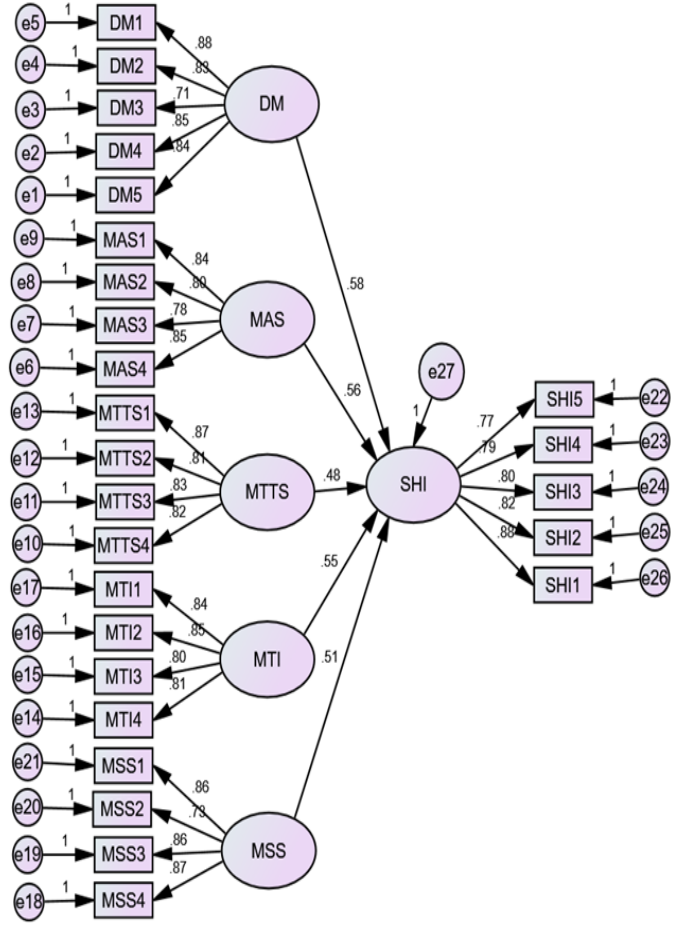

Figure 2. Structural path analysis results for the study model 
Table 3 showed summary results for the test of the study hypotheses $\left(\mathrm{H}_{1}-\mathrm{H}_{5}\right)$. The result of $\mathrm{H}_{1}$ showed that destinations management has a significant positive effect on the sustainability of hospitality industry $(\beta=0.58 ; p=0.00)$. Therefore, $\mathrm{H}_{1}$ was supported, implying that a $1 \%$ increase in destinations management will result in a $58 \%$ increase on the sustainability of hospitality industry. In examining $\mathrm{H}_{2}$, the result showed that management of attraction sites has a significant positive effect on the sustainability of hospitality industry $(\beta=0.56 ; p=0.00)$, which supported the initial hypothesis $\mathrm{H}_{2}$. This result indicated that a $1 \%$ increase in the management of attraction sites will result to a $56 \%$ increase on the sustainability of hospitality industry. Furthermore, the result supported $\mathrm{H}_{3}$, that management of tourist transportation systems has a significant positive effect on the sustainability of hospitality industry $(\beta=0.48 ; \mathrm{p}=0.00)$. Consistent with $\mathrm{H}_{3}$, the result revealed that when management of tourist transportation systems increase by $1 \%$, sustainability of hospitality industry accordingly increases by $48 \%$. Similarly, the result of $\mathrm{H}_{4}$ revealed that management of tourism intermediaries has a significant positive effect on the sustainability of hospitality industry $(\beta=0.55 ; p=0.00)$. Consequently, $\mathrm{H}_{4}$ was supported inferring that a $1 \%$ increase in management of tourism intermediaries will lead to a $55 \%$ increases on the sustainability of hospitality industry.

Finally, $\mathrm{H}_{5}$ indicated that management of security system has a significant positive effect on the sustainability of hospitality industry $(\beta=0.51 ; p=0.00)$. On the basis of this result, when management of security system increases by $1 \%$, it leads to a $51 \%$ increase on the sustainability of hospitality industry. Therefore, test of the study hypotheses showed that tourism management has a significant positive effect on the sustainability of hospitality industry.

Table 3. Summary results for the test of hypotheses

\begin{tabular}{|c|c|c|c|c|c|c|}
\hline Hypotheses & Variables & path & Variables & $\begin{array}{l}\text { Standardi- } \\
\text { Zed beta }(\beta)\end{array}$ & $\begin{array}{c}\text { p- } \\
\text { Value }\end{array}$ & Result \\
\hline$H_{l}$ & $\begin{array}{c}\text { Sustainability of } \\
\text { Hospitality industry (SHI) }\end{array}$ & $<--$ & Destinations Management (DM) & 0.58 & 0.000 & Supported \\
\hline $\mathrm{H}_{2}$ & $\begin{array}{c}\text { Sustainability of } \\
\text { Hospitality industry (SHI) }\end{array}$ & $<--$ & Management of Attraction (MAS) & 0.56 & 0.000 & Supported \\
\hline$H_{3}$ & $\begin{array}{c}\text { Sustainability of } \\
\text { Hospitality industry (SHI) }\end{array}$ & $<--$ & $\begin{array}{c}\text { Management of Tourist } \\
\text { Transportation System (MTTS) }\end{array}$ & 0.48 & 0.000 & Supported \\
\hline$H_{4}$ & $\begin{array}{c}\text { Sustainability of } \\
\text { Hospitality industry (SHI) }\end{array}$ & $<--$ & $\begin{array}{l}\text { Management of Tourism } \\
\text { Intermediaries (MTI) }\end{array}$ & 0.55 & 0.000 & Supported \\
\hline $\mathrm{H}_{5}$ & $\begin{array}{c}\text { Sustainability of } \\
\text { Hospitality industry (SHI) }\end{array}$ & $<--$ & $\begin{array}{c}\text { Management of Security System } \\
\text { (MSS) }\end{array}$ & 0.51 & 0.000 & Supported \\
\hline
\end{tabular}

\section{DISCUSSION}

The study results further expounded the implication of tourism management on the sustainability of hospitality industry. After conducting the test of hypotheses, the findings from $\mathrm{H}_{1}$ showed that destinations management has a significant positive effect on the sustainability of hospitality industry. The finding was established after obtaining a standardized beta value of 0.58 and a significant p-value of 0.00 which supported the initial $\mathrm{H}_{1}$ that destinations management has a significant effect on the sustainability of hospitality industry. Aligning with this finding Timareva et al. (2015) indicated that destination management enhances tourism development and impact on the performance of hospitality firm. Similarly, Iwara et al. (2017) indicated that effective destination management improved the provision of modern facilities, accommodations, amenities, enhanced security and continuous improvement of services offered in destinations, thereby providing memorable tourist and visitors experience as well as increasing tourist/visitors influx in the destinations which results in increased revenue generation as well as sustainability of the hospitality industry. Furthermore, the study result was supported by Zemla (2016), that effective destination management enhances the development of the destinations, tourism supply, facilities/infrastructure, improve services and attract repeat visit by tourist and visitors to the destination.

Similarly, findings from $\mathrm{H}_{2}$ revealed that management of attraction sites has a significant positive effect on the sustainability of hospitality industry. The finding confirms the initial $\mathrm{H}_{2}$ that management of attraction sites has a significant effect on the sustainability of hospitality industry. The finding was reached after obtaining a standardized beta value of 0.56 and a $\mathrm{p}=$ value of 0.00 . Supporting this finding, Leask (2016) in his study indicated that effective management of attractions sites increases the potentials of a destination and enhances tourist and customers' patronage, since a well-managed and developed attraction sites grab tourist attention and entice them for a visit thereby increasing the influx of tourist and visitors in a destination. Similarly, the result corroborates the study of Mazilu (2010) who indicated that adequate management of parks and other attraction sites impact significantly on the development and growth of tourism in a nation. Similarly, study by Richards (2002) revealed that attractions sites relates significantly with the performance of the tourism industry.

Furthermore, the result supported $\mathrm{H}_{3}$, that management of tourist transportation systems has a significant positive effect on the sustainability of hospitality industry. The finding was evidenced by a significant $\mathrm{p}$-value of 0.000 and a standardized beta value of 0.48. However, supporting the finding, prior studies, particularly, Lomhmann and Duval (2011) indicated that improved management of transportation systems increases transportation options for recreational travel to destinations and attraction sites as well as reducing traffic in destinations and attractions sites. Accordingly, Alasgarova (2017) revealed that adequate tourist transportation systems impact significantly on the growth of destinations and attraction sites as well as the performance of hospitality firms. Also, Palhares (2003) indicated that accessibility to tourism destinations through modern and improved transportation systems increase the viability of destinations and attraction sites and lead to increase revenue generation for the sustainability of hospitality industry. 
However, the result of $\mathrm{H}_{4}$ supported the initial hypothesis and revealed that management of tourism intermediaries has a significant positive effect on the sustainability of hospitality industry with a standardized beta value of 0.55 and significant value of 0.00 . Corroborating this finding, Mazilu (2010) indicated that effective management of tourism intermediaries enhances performance of destinations and hospitality industry. Also supporting the finding, Foris et al. (2020) asserted that management of tourism intermediaries is vital, since their services impact significantly on potential tourist and marketing of tourism products which could encourage tourist visit to the destination as well as increasing the revenue of the destinations and hospitality industry. Richards (2002) indicated that management of tourism intermediaries impacts on the performance of destinations and hospitality industry.

Finally, $\mathrm{H}_{5}$ indicated that management of security system has a significant positive effect on the sustainability of hospitality industry. The result was obtained based on a standardized beta value of 0.51 and a p-value of 0.000 , which supported the initial hypothesis that management of security system has a significant effect on the sustainability of hospitality industry. Supporting the finding Adora (2010) in his study indicated that without effective security, tourists cannot successfully explore or visit attraction sites or destinations. The perception of security and safety of a destination by tourist and visitors influence tourist intention to visit a destination as well as encouraging repeat visit to a destination. Also, Hamarneh and Jerabek (2018) stressed that effective security management ensure access control that enables only authorized persons, tourist and visitors access to tourism destinations in order to maintain security of the destination for improved tourist comfort. Similarly, Brondoni (2016) highlighted that effective security management increase the security and safety of destination and impact significantly on the performance of hospitality industry.

\section{CONCLUSION}

Tourism management has been a crucial feature of the business landscape and plays important role on the sustainability of hospitality industry and economic development of nations, particularly developing countries. However, poor tourism management and neglect of tourism sector in many developing countries impeded the development of tourism ecosystem in many countries for obvious reasons. To this end, this study explored the effect of tourism management as a panacea for sustainability of hospitality industry. Five core variables that act as catalyst to effective tourism management were utilized in the study: destinations management, management of attraction sites, management of tourist transportation systems, management of tourism intermediaries, and management of security system.

The results indicated that five hypotheses examining in the study were all supported and confirmed. Specifically, the results showed that destinations management has a significant positive effect on the sustainability of hospitality industry. Similarly, management of attraction sites has a significant positive effect on the sustainability of hospitality industry. Also, management of tourist transportation systems has a significant positive effect on the sustainability of hospitality industry. Accordingly, management of tourism intermediaries has a significant positive effect on the sustainability of hospitality industry. Lastly, management of security system has a significant positive effect on the sustainability of hospitality industry.

Therefore, it is concluded that effective destinations management, management of attraction sites, tourist transportation systems, tourism intermediaries and security system is vital for the development and growth of the tourism sector and significantly enhance the sustainability of hospitality industry as well as economic growth of nations. In other words, effective tourism management and adoption of workable strategies become germane towards enhancing the tourism ecosystem and sustainability of hospitality industry. Importantly, the results of the study have significant theoretical and practical implications. First the study contributed to the literature on tourism management from a developing country context. From the practitioner's perspective, the results of the study provided a better understanding of the implications of effective tourism management on the sustainability of hospitality industry, particularly in developing countries.

However, the research was geographically limited to the selected hotels, packs and tourism destinations and attraction sites in Cross River State, Nigeria. Also, the study was limited to five variables of tourism management. As such, other components of tourism management not covered in this study posed a limitation to the research. Therefore, future studies should seek to examine other tourism management dimensions not covered in this study to explain the significance on sustainability of hospitality industry. Also, this study should be replicated in different regions and continent with a different cultural background using a longitudinal survey to ascertain the generalizability of the result of the present study.

\section{REFERENCES}

Adora, C.U. (2010). Managing tourism in Nigeria: The security option. Management Science and Engineering, 4(1), 14-25. www.cscanada.net

Alasgarova, F. (2017). The role of tourism transport's development in economic growth. Annals of Spiru Haret University Economic Series, 3, 85-92. https//www.anale.spiruhret.ro/

Barišiü, P., \& Mariü, I. (2012). The role of management as a strategic tourism guideline: Case of Croatia. International Journal of Business and Management Studies, 1(2), 423-431. http//univesitypublications.net

Brebbia, C.A., \& Pineda, F.D. (2012). Sustainable tourism V: With transactions on ecology and the environment ( $1^{\text {st }}$ Ed). Boston: WITPress.

Brondoni, S.M. (2016). Global tourism and terrorism. Safety and security management, symphony. Emerging Issues in Management, 2 , 7-16. https://symphonya.unimib.it

Chia, S.K., Lo, M., Razak, Z.B., Wang, Y.C., \& Mohamad, A.A. (2021). Impact of destination image on tourist satisfaction: The moderating effect of information technology (IT). GeoJournal of Tourism and Geosites, 34(1), 88-93. https://doi.org/10.30892/gtg34112-623

Eden, S. (2005). Rethinking the role of transportation in tourism. Proceedings of the Eastern Asia Society for Transportation Studies, 5, 1767-1777

Ekundayo, I.M., Joram, N., \& Nokuthula, C. (2018). Events as perceived panacea for sustainable tourism development in Durban, South Africa. Journal of Good Governance and Sustainable Development in Africa 4(2), 90-101. http://www.rcmss.com/index.php/ijpamr 
Foris, D., Florescu, A., Foris T., \& Barabas, S. (2020). Improving the management of tourist destinations: A new approach to strategic management at the DMO level by integrated lean techniques. Sustainability, 12, 1-22. https://doi.org/10.3390/su122310201

Fornell, C., \& Larcker, D. (1981). Evaluating structural equation models with unobservable variables and measurement error. Journal of Marketing Research, 18(1), 39-50. https//doi.org/10.2307/3151312

Gaetano, G., Emmanuil, T., Tiziana L., \& Silvia F. (2021). Prospective tourist preferences for sustainable tourism development in small island developing states. Tourism Management, 82, 104178. https://doi.org/10.1016/j.tourman.2020.104178

Goffi, C., Cucculelli, M., \& Masiero, L. (2019). Fostering tourism competitiveness in developing countries: The role of sustainability, 209, 101-115. https://doi.org/10.1016/J.JCLEPRO.2018.10.208

Hamarneh, I., \& Jerabek, P. (2018). The impact of the security situation on tourism in the countries of the former Yugoslavia. International Scientific Journal Security and Future, 3, 111-115.

Hair, JR, J. F., Black, W. R., Babin, B. J., \& Anderson, R. E. (2010). Multivariate data analysis (7th ed.). Upper Saddle River, NJ: Prentice Hall.

Isidoro, R., \& Pilar, T. (2020). Tourism intermediaries and innovation in the hotel industry. Current Issues in Tourism, 23(5), 641-653. https://doi.org/10.1080/13683500.2019.1572717

Iwara, E.E., Bassey, A.L., \& Iji, M.E. (2017). Assessing private sector as a panacea for destination development: A case study of the hospitality industry in Calabar, Nigeria. Journal of Tourism and Management, 2(1), 44-56. https://doi.org/10.26465/ojtmr.2017219494

Kanellou, D. (2005). The new role of intermediaries in travel and tourism distribution channels. Brussels: European Commission Joint Research Centre.

Keskin, K., \& Ucal, M.A. (2021). A dynamic game theory of model for tourism supply chains. Journal of Hospitality and Tourism Research, 45(2), 304-324. https://doi.org/10.1177/1096348020913949

Kline, R.B. (2015). Principles and practice of structural equation modelling (4 ${ }^{\text {the }}$ ed.). New York: Guilford Press.

Leask, A. (2016). Visitor attraction management: A critical review of research 2009-2014. Tourism Management, 57, 334-361. https://doi.org/10.1016/J.tourman.2016.06.015

Lomhmann, G., \& Duval, D. (2011). Critical aspects of the tourism-transport relationship. Contemporary Tourism Review. Oxford: Goodfellow Publishers.

Malheiro, A., Sousa, B.B., Liberato, D., \& Liberator, P. (2020). Sustainability in tourism and hospitality: Trends and challenges. A paper presented at the $35^{\text {th }}$ IBIMA Conference, Seville, Spain. 1-2 April, 2020.

Mazilu, M. (2010). Key elements of a model for sustainable tourism. International Journal of Energy and Environment, 2(4), 45-54.

Palhares, G.L. (2003). The role of transport in tourism development: Nodal Functions and management practices. International Journal of Tourism Research, 5, 403-407. https://doi.org/10.1002/jtr.446

Paresashvili, N., \& Maisuradze, T. (2016). Destination management role in developing tourism in Georgia. International Scientific and Practical Conference World Science, 4(8), 46-50.

Richards, G. (2002). Tourism attraction systems. Annals of Tourism Research, 29(4), 1048-1064. https://doi.org/10.1016/S01607383(02)00026-9

Sanhakot, V. (2021). COVID-19 pandemic: A testing time for tourism and hospitality in Thailand. ABAC ODI Journal of Vision Action Outcome, 8(1), 41-53. http:/www.assumptionjournal.au/edu/index.php/odijournal

Setokoe, T.J. (2021). Community-based tourism: A panacea for community development in Nqileni village, Eastern Cape, South Africa. GeoJournal of Tourism and Geosites, 34(1), 28-32. https://doi.org/10.30892/gtg.34104-615

Soteriades, M. (2012). Tourism destination marketing: Approaches improving effectiveness and efficiency. Journal of Hospitality and Tourism, 3(2), 107-120. https://doi.org/10.1108/17579881211248781

Timareva, S., Arabska, E., \& Shopova, I. (2015). Role of destination management and marketing organisations in regional development. Trakia Journal of Sciences, 13(1), 96-102. https://doi.org/10.15547/tjs.2015.s.01.016

Todorut, A.V., \& Cîrnu, D. (2012). The effects of sustainable tourism management for local communities. Annals of the Constantin Brâncuşi University of Târgu Jiu, Economy Series, 2, 154-160.

Tolulope, T.O., Olufemi, B.O., Mosab, I.T., Adedoyin, O.A., \& Dang, K.T. (2021). The impact of corruption on tourism sector in Nigeria: Empirical insight by using an autoregressive distributed lag bound (ARDL) testing approach. International Journal of Hospitality and Tourism Administration, 22(2). https://doi.org/10.1080/15256480.2021.1905583

Unhasuta, S., Sasaki, N., \& Kim, S.M., (2021). Impact of tourism development on coastal communities in cha-am beach, the gulf of Thailand, through analysis of local perceptions. Sustainability, 13(4423), 1-23. https://doi.org/10.3390/su13084423

Vengesayi, S., Mavondo, F., \& Reisinger, Y. (2009). Tourism destination attractiveness: Attractions facilities, and people as a predictor. Tourism Analysis, 14(5), 621-636. https://doi.org/10. 3727/108354209X1259795935211

Villanueva-Álvaro, J., Mondéjar-Jiménez, J., \& Sáez-Martínez, F. (2017). Rural tourism: development, management and sustainability in rural establishments. Sustainability, 9(818), 1-8. https://doi.org/10.3390/su9050818

World Tourism Organisation (2021). Tourism and rural development. Geneva: WIPO. https://doi.org/10.18111/9789284422

Zemla, M. (2016). Tourism destination: The networking approach. Moravian Geographical Reports, 24(4), 2-14. https://doi.org/10.1515/mgr-2016-0018

Article history: Received: 12.04.2021 Revised: 07.07.2021 Accepted: 17.08.2021 Available online: 03.09.2021 